\title{
Preparation of Red Palm Weevil Rhynchophorus Ferrugineus (Olivier) (Coleoptera: Dryophthoridae) Germ-free Larvae for Host-gut Microbes Interaction Studies
} Abrar Muhammad ${ }^{1,2}$, Prosper Habineza ${ }^{1,2}$, Youming Hou' ${ }^{1,2}$ and Zhanghong Shi', 2, *

${ }^{1}$ State Key Laboratory of Ecological Pest Control for Fujian and Taiwan Crops, Fujian Agriculture and Forestry University, Fuzhou, 350002, China; ${ }^{2}$ Fujian Provincial Key Laboratory of Insect Ecology, College of Plant Protection, Fujian Agriculture and Forestry University, Fuzhou, 350002, China *For correspondence: shizh@fafu.edu.cn

[Abstract] Red palm weevil (RPW), Rhynchophorus ferrugineus Olivier, is a devastating pest of palm trees worldwide. RPW gut is colonized by diverse bacterial species which profoundly influence host development and nutritional metabolism. However, the molecular mechanisms behind the interactions between RPW and its gut microbiota remain mostly unknown. Antibiotics are usually employed to remove gut bacteria to investigate the impact of gut bacteria on insect fitness. However, administration of antibiotics cannot thoroughly remove gut bacteria for most insect species. Therefore, establishing germfree (GF) organisms is a powerful way to reveal the mutual interactions between gut bacteria and their insect hosts. Here, we describe a protocol to generate and maintain RPW GF larvae, being completely devoid of gut bacteria in laboratory. RPW GF larvae were established from the dechorionated fresh eggs which were reared on the sterilized artificial food under axenic conditions. The establishment of GF larvae set a solid foundation to deeply elucidate the molecular mechanisms behind the interactions between RPW and its gut microbiota.

Keywords: Rhynchophorus ferrugineus, Germfree larvae, Gut microbiota, Insect symbiosis, Host physiology

[Background] Red palm weevil, Rhynchophorus ferrugineus (Olivier) (Coleoptera: Dryophthorodae), is one of the most noxious pest of palm trees in the world (Li et al., 2009; Ju et al., 2011; Al-Dosary et al., 2016; Peng et al., 2016). It is native to south Asia and Melanesia, but recently it has dramatically spread to European, African, some American and other Asian countries (OEPP/EPPO, 2008; Shi et al., 2014). The larva of RPW is the main destructive agent which feed on tender tissues and sap in the trunk from the apical growing point of palms. RPW larvae complete its entire developmental time inside the palm trunk until newborn adults fly out for locating new oviposition sites (Kaakeh, 2005; OEPP/EPPO, 2008; El-Mergawy and Al-Ajlan, 2011). The concealed infestation behavior of the pest makes its control more challenging. Currently, the control measures against this insect pest include the use of synthetic insecticides, phyto-sanitation, pheromone-based mass trapping and releasing some biological control agents, such as entomopathogenic fungi, bacteria and nematodes (Murphy and Briscoe, 1999; Faleiro, 2006; Mazza et al., 2014; Pu and Hou, 2016). However, due to the occurrence of pesticide resistance and limitations of other control measures, it is urgent to develop some 
sustainable, eco-friendly and economical manage strategies that can effectively protect palm trees from this insect pest.

Like mammals, insects live in the symbiotic associations with gut microbiota which play thecritical roles in many host physiological processes, containing development, digestion and detoxification, immunity and chemical communication (Douglas, 2009, 2010 and 2015; Engel and Moran, 2013). Gut bacteria are the excellent agents for paratransgenesis by using an engineered symbiont to express some specific bioactive molecules that impair insect fitness to achieve pest control (Engel and Moran, 2013). Therefore, elucidating the interactions between insect pests and their symbiotic microbes could provide some important implications for the development of novel pest management tactics (Butera et al., 2012; Crotti et al., 2012).

Owing to its enormous economic and environmental losses, RPW has attracted great attention in recent years. Recently, some preliminary investigations have deciphered gut bacterial components of RPW larvae and adults. It has been determined that RPW gut is colonized by bacteria mainly from Enterobacteriaceae, Lactobacillaceae, Acetobacteriaceae, Entomoplasmataceae, Enterococcaceae and Streptococcaceae (Jia et al., 2013; Tagliavia et al., 2014; Montagna et al., 2015; Muhammad et al., 2017). Moreover, we have discovered that a secretory protein, RfPGRP-LB, and the NF-KB like transcription factor, RfRelish, regulate gut immunity to modulate the homeostasis of RPW gut microbiota (Dawadi et al., 2018; Xiao et al., 2019). Furthermore, it has also been found that gut microbiota of RPW can affect its host growth and development by modulating its nutrition metabolism (Muhammad et al., 2017; Habineza et al., 2019). Unfortunately, we found gut bacteria of RPW larvae cannot be removed thoroughly by the administration of antibiotic cocktails (Muhammad et al., 2017). Increasing evidence strongly suggest that GF animal models are one of pivotal tool for dissecting the crosstalks between animal and their gut microbiota (Grover and Kashyap, 2014; Koyle et al., 2016; Kietz et al., 2018). Therefore, to investigate the role of residential gut microbiota on RPW physiology, RPW GF larvae were generated to decipher the host-gut bacteria interplays. Compared with the administration of antibiotics, our protocol in the report can successful and easily to establish and maintain RPW GF larvae. It is also easy to generate the gnotobiotic RPW larvae with specified gut bacterial species.

\section{Materials and Reagents}

1. Perforated plastic bottles $(330 \mathrm{ml}, 70 \mathrm{~mm} \varnothing, 107 \mathrm{~mm}$ height; Jiafeng Horticultural Products Co. Ltd., Chongqing, China)

2. Conical flask

3. Petri dishes (90 mm Ø, Yancheng Huida Medical Instruments Co. Ltd., Jiangsu, China)

4. Paintbrush (1 $\mathrm{cm}$ width), used to collect the fresh eggs

5. $0.22 \mu \mathrm{m}$ syringe filters (Pall Corporation, USA)

6. Spatula (20 cm long and $4 \mathrm{~cm}$ wide at the tip)

7. PCR tubes (Biosharp Life Sciences, Hefei, China) 
8. $1.5 \mathrm{ml}$ microcentrifuge tubes (Biosharp Life Sciences, Hefei, China)

9. Metal sieve with pore size $60 \mu \mathrm{m}$ (Sigma-Aldrich Co. Ltd., Switzerland, catalog number: Z289744)

10. Aluminum foil

11. Parafilm (Bemis PM-996, USA)

12. $10 \mathrm{ml}$ sterile syringes (Hamilton ${ }^{\circledR}$ Syringes, Sigma-Aldrich Co. Ltd., Switzerland)

13. Filter paper (90 mm $\varnothing$, Fuyang Special Paper Industry Co. Ltd., Hangzhou, China)

14. Sugarcane, Saccharum sinensis Roxb. (Zhangzhou City, Fujian Province, China)

15. Primers for amplifying the bacterial 16S rRNA gene (27F: 5'-AGAGTTTGATCATGGCTCAG-3', 1492R: 5'-TACGGYTACCTTGTTACGACTT-3') (Sangon BioTech. Co. Ltd., Shanghai, China)

16. Trans $2 \mathrm{~K}^{\circledR} \mathrm{DNA}$ marker (Transgene BioTech. Co. Ltd., Beijing, China)

17. Distilled water

18. Ethanol (Sigma-Aldrich, CAS number: 64-17-5)

19. Sodium hypochlorite ( $\mathrm{NaClO}$ ) (Sigma-Aldrich, CAS number: 7681-52-9)

20. Antibiotics
a. Kanamycin (Sigma-Aldrich, CAS number: 70560-51-9)
b. Tetracycline (Sigma-Aldrich, CAS number: 64-75-5)
c. Gentamycin (Sigma-Aldrich, CAS number: 1405-41-0)
d. Erythromycin (Sigma-Aldrich, CAS number: 114-07-8)

21. Tryptone (OXOID, catalog number: 2406419)

22. Sodium chloride ( $\mathrm{NaCl})$ (Sigma-Aldrich, CAS number: 746398)

23. Potassium chloride (KCl) (CAS number: 7447-40-7)

24. Anhydrous sodium phosphate dibasic $\left(\mathrm{Na}_{2} \mathrm{HPO}_{4}\right)$ (CAS number: 7558-79-4)

25. Hydrochloric acid ( $\mathrm{HCl}$ ) (CAS number: 7647-01-0)

26. Monopotassium phosphate $\left(\mathrm{KH}_{2} \mathrm{PO}_{4}\right)$ (CAS number: 7778-77-0)

27. Yeast extract (CAS number: 8013-01-2)

28. Agar (CAS number: 9002-18-0)

29. Sodium hydroxide $(\mathrm{NaOH})(\mathrm{CAS}$ number: 221465$)$

30. DNA extraction kit (DNeasy blood and tissue kit, Qiagen, Germany)

31. 6x DNA Loading buffer (TRANS ${ }^{\circledR}$, Transgene BioTech. Co. Ltd., Beijing, China)

32. 0.5x TAE buffer (Tris-Acetate EDTA)

33. $2 x$ Taq PCR Mastermix (Tiangen Biotechnology, Beijing, China)

34. Tris- $\mathrm{HCl}$ (Solarbio Life Sciences Co. Ltd., Beijing, China)

35. Glacial acetic acid (CAS number: 64-19-7)

36. Ascorbic acid

37. Sucrose

38. Casein

39. Corn flour

40. Avicel 
41. Cholestrol

42. Choline chloride

43. Inositol

44. Potassium sorbate

45. Sodium p-hydroxybenzoate

46. Disodium EDTA (CAS number: 6381-92-6)

47. Agarose (Transgen. Biotech. Co. Ltd., Beijing, China)

48. TRANS ${ }^{\circledR}$ Ethidium bromide Gel Stain (Transgen. Biotech. Co. Ltd., Beijing, China)

49. 10x PBS stock solution (see Recipes)

50. Antibiotic stock solution (see Recipes)

51. LB agar medium (see Recipes)

52. 10x TAE stock solution (see Recipes)

53. The artificial food for RPW larvae (see Recipes)

\section{Equipment}

1. Heal Force safe-1200LC biosafety cabinet (Heal Force Bio-meditech Holdings Co. Ltd., Shanghai, China)

2. Autoclave (Shennan LDZF-75KB-II, China)

3. SCIENTZ-48 tissue lyser (Ningbo Scientz Botecthnology Co., Ltd, China)

4. Haier refrigerator (Haier Co. Ltd., Qingdao, China)

5. Scissors (World Precision Instruments, Sarasota, USA)

6. Pointed tip tweezers $(3.9 \times 3.0 \times 1.0$ inches, World Precision Instruments, Sarasota, USA)

7. Forceps with curved flat rounded tips $(1.65 \mathrm{~mm} \times 0.05 \mathrm{~mm} \times 120 \mathrm{~mm}$, width $\times$ thickness $\times$ length, World Precision Instruments, Sarasota, USA)

8. Yiheng ${ }^{\circledR}$ Incubator $(500 \times 460 \times 800 \mathrm{~mm}$, Shanghai Yiheng Instruments Co. Ltd., China) was employed to rear the axenic larvae (The conditions were set at $37^{\circ} \mathrm{C}$ and dark for $24 \mathrm{~h}$ )

9. BIO-RAD T100 ${ }^{\mathrm{TM}}$ PCR thermocycler (Bio-Rad Co. Ltd., USA)

10. Eppendorf 5804 R Centrifuge (Eppendorf Co. Ltd., Germany)

11. Gel electrophoresis unit (Liuyi Instruments Co. Ltd., Beijing, China)

12. Nikon ${ }^{\circledR}$ Stereomicroscope (Nikon Co. Ltd., Japan)

13. Saifu ZRX-260 incubator for maintaining the RPW lab population (260 L, Ningbo Experimental Instrument Co. Ltd, China)

14. Nanodrop 1000 (Thermo SCIENTIFIC, USA)

15. Microwave (Midea Co. Ltd., Guangdong, China)

16. Magnetic stirrer (Ronghua Experimental Instrument Co. Ltd., Jintan, Jiangsu, China)

17. BSA124S Electric balance (Sartorius Co. Ltd., Germany)

18. UV transilluminator (Peiqing Science and Technology Co. Ltd., China)

19. Laminar hood (Heal Force Safe-1200LC) 


\section{Software}

1. IBM SPSS Statistics (22.0)

\section{Procedure}

A. Insect rearing and maintaining

1. RPW lab population was established and maintained by the adults which were trapped in Pingtan District $\left(119^{\circ} 32^{\prime} \mathrm{E}, 2^{\circ} 31^{\prime} \mathrm{N}\right)$ of Fuzhou City, Fujian Province and Jinshan campus of Fujian Agriculture and Forestry University (119 $\left.30^{\prime} \mathrm{E}, 26^{\circ} 08^{\prime} \mathrm{N}\right)$. RPW individuals were fed with sugarcane stems in the incubator (Saifu ZRX-260, Ninbo Experimental Instrument Co. Ltd., China) at the condition of $27 \pm 1{ }^{\circ} \mathrm{C}, 75 \pm 5 \%$ relative humidity, and a photoperiod of $24 \mathrm{~h}$ dark for larvae and $12 \mathrm{~h}$ light/12 $\mathrm{h}$ dark for adults $(35 \mathrm{~mm} \times 10 \mathrm{~mm}$, length $\mathrm{x}$ width, Figure 1).

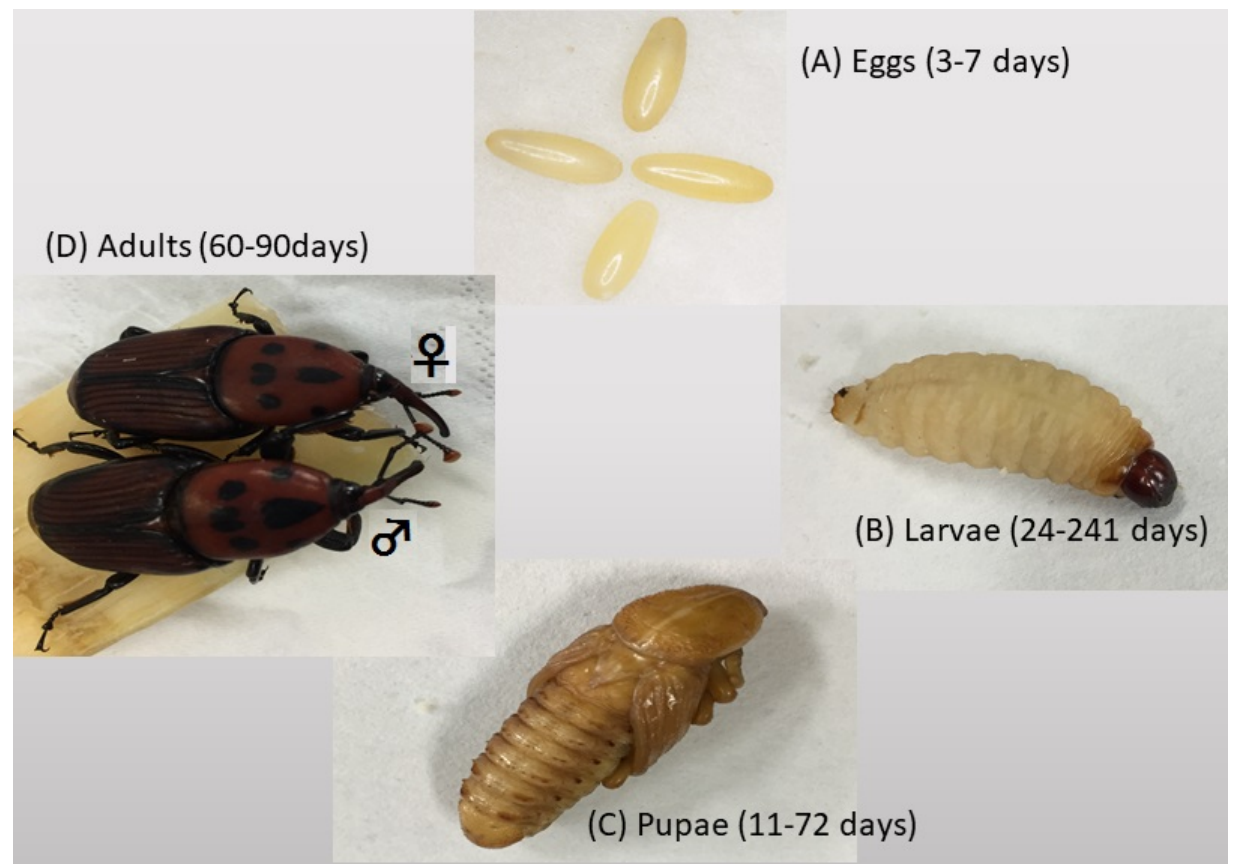

Figure 1. The four different life stages of red palm weevil, Rhynchophorus ferrugineus

2. A female and male RPW adult were kept in the perforated plastic bottle. Provide them with sugarcane stem slices (30 mm x $15 \mathrm{~mm}$, length $\mathrm{x}$ width) for feeding and oviposition. The food was changed every three days.

3. The fresh eggs within $12 \mathrm{~h}$ after being laid were collected by cutting the sugarcane stem slices into much thinner ones, for dechorionation to generate RPW GF larvae.

B. Preparation of artificial food and antibiotic stock solutions

1. Make RPW artificial food (see Recipe 1) and prepare antibiotics stock solutions (see Recipe 2).

2. Syringe filter $(0.22 \mu \mathrm{m})$ the antibiotics stock solution and store in aliquots. 
3. Prepare the artificial food in an autoclavable $1 \mathrm{~L}$ conical flask and sterilize it using an autoclave for $20 \mathrm{~min}$ at $121^{\circ} \mathrm{C}$.

4. Add the antibiotic cocktail ( $600 \mathrm{mg} / \mathrm{kg}, 150 \mathrm{mg} / \mathrm{kg}$ each) and $1 \mathrm{~g}$ ascorbic acid to the autoclaved artificial food when the temperature drops to about $55^{\circ} \mathrm{C}$.

5. After solidification, prepare a parallel batch of the artificial diet without antibiotics, replaced by the same volume of sterile distilled water.

6. After solidification, prepare aliquots of the artificial food in Petri dishes and seal it with parafilm to avoid the potential microbial contamination during changing food for RPW individuals.

Note: Carry out this step in the biosafety cabinet.

7. Diet can be stored at $4{ }^{\circ} \mathrm{C}$ for later use.

C. Generating RPW GF individuals via egg dechorionation

1. Sterilize all the tools, containing paintbrush, metal sieve, spatula $(20 \mathrm{~cm} \times 4 \mathrm{~cm}$, length $\mathrm{x}$ width), tweezers and forceps, with $75 \%$ ethanol.

2. Turn on the UV light for 30 min to sterilize the surface of laminar hood and other materials inside.

3. Divide the eggs into two groups: a) non-dechorionated (control group) and b) dechorionated eggs. Use 30 eggs in each group.

4. For eggs dechorionation, process the dechorionated eggs with the following steps as Koyle et al. (2016):

a. Wash the freshly laid eggs with $10 \%$ sodium hypochlorite solution $(\mathrm{NaClO})$ for 3-5 min and then filter them through the metal sieve.

b. Rinse these eggs two times with $75 \%$ ethanol and filter through the metal sieve.

c. Wash these eggs twice with sterilized distilled water to wash off the bleach $(\mathrm{NaClO})$ and ethanol and filter the water carrying dechorionated eggs through the metal sieve. For the eggs in control group, they are only washed with the autoclaved distilled water and then filter the water carrying eggs through a metal sieve.

5. Observe the dechorionated eggs under a stereomicroscope and we found that the dechorionated eggs became white as compared to the controls (Figure 2). 


\section{A. Non-dechorionated}

Figure 2. Non-dechorionated and dechorionated eggs of red palm weevil, distilled water only and (B) dechorionated eggs were washed with $10 \%$ sodium hypochlorite solution ( $\mathrm{NaClO}$ ), $75 \%$ ethanol and sterilized distilled water.

6. Transfer the dechorionated eggs to the sterilized Petri dishes $(90 \mathrm{~mm} \varnothing)$ with some UV sterilized moist absorbent cotton inside the laminar hood (Heal Force Safe-1200LC). The eggs are allowed to hatch inside the laminar hood at the condition of $27 \pm 1^{\circ} \mathrm{C}$ and $75 \pm 5 \%$ relative humidity in the dark.

7. Observe the eggs for hatching every $24 \mathrm{~h}$. Two to three days later, they will hatch.

8. Transfer the neonatal larvae to the new sterilized Petri dishes with $3 \mathrm{~g}$ solid artificial diet (Step C6), with or without antibiotics. Refresh the food every two days.

9. Maintain the RPW larvae at $27 \pm 1^{\circ} \mathrm{C}, 75 \pm 5 \%$ relative humidity, and $24 \mathrm{~h}$ dark photoperiod.

10. Change the artificial food every three days.

11. To verify the efficiency of our protocol, four groups are designated here: 1) dechorionated eggs + food with antibiotics, 2) dechorionated eggs + food without antibiotics (DNA), 3) non-dechorionated eggs + food with antibiotics (NDA), and 4) non-dechorionated eggs + food without antibiotics (CR conventionally reared). The larvae in Groups 1 and 3 are maintained in the laminar hood, while two other groups, be served as the positive and negative control, are kept in the incubator (Ninbo Experimental Instrument).

D. Verification of germfree RPW individuals with culture-dependent and -independent assays

\section{Gut dissection and homogenization}

1. To validate the GF status of RPW, randomly select three larvae (the 5th instar larvae, Figure 3) from each treatment as a replicate for dissection, each group compromised at least three replicates. 
Please cite this article as: Muhammad et. al., (2019). Preparation of Red Palm Weevil Rhynchophorus Ferrugineus (Olivier) (Coleoptera: Dryophthoridae) Germ-free Larvae for Host-gut Microbes Interaction Studies,Bio-protocol 9 (24): e3456. DOI: 10.21769/BioProtoc.3456.

2. To remove the potential effect of associated microbes on the body surface of RPW larvae, submerge the specimens in $10 \% \mathrm{NaClO}$ for $30 \mathrm{~s}, 75 \%$ ethanol for $90 \mathrm{~s}$ and two rinses with sterile distilled water. This step is completed inside the laminar hood.

3. Dissect the guts under a stereomicroscope using sterilized scissors and forceps in a clean Petri dish with sterile PBS.

4. Homogenize the collected guts in $1.5 \mathrm{ml}$ microcentrifuge tube containing $1 \mathrm{ml}$ sterile PBS, using a tissue lyser (48 tissue lyser Ningbo Scientz BioTech. Co. Ltd, China).

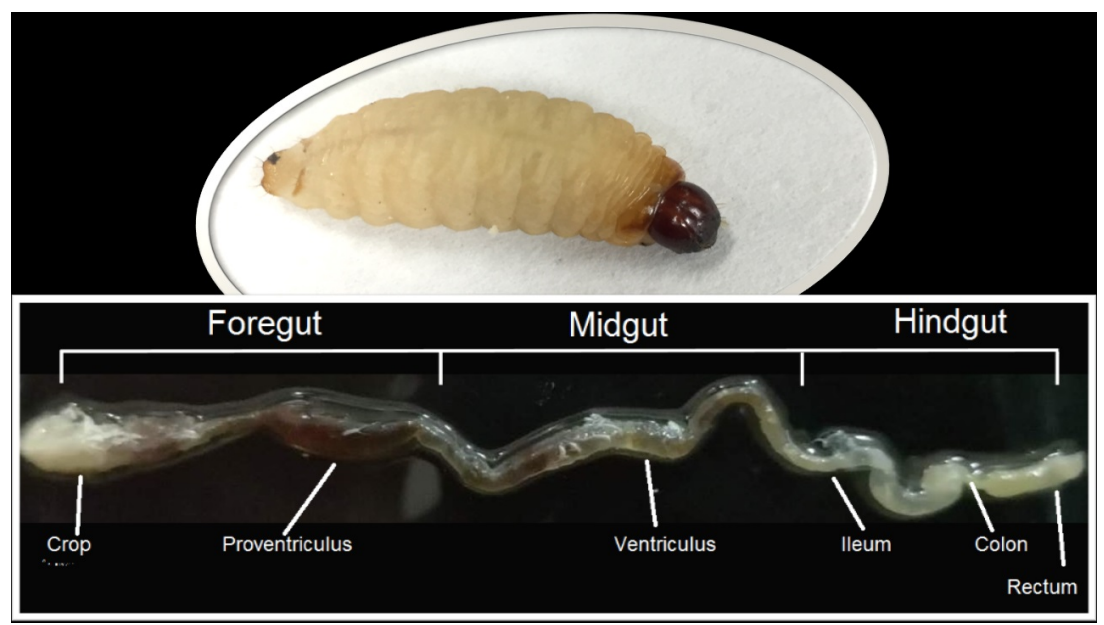

Figure 3. The gut from the fifth RPW larvae

\section{Verification of germfree RPW individuals with culture-dependent assays}

1. Serially dilute $\left(10^{-1}-10^{-4}\right.$ fold $)$ the gut homogenate with sterile PBS.

2. Plate $100 \mu \mathrm{l}$ diluted homogenate on the LB agar plate in triplicate.

3. Incubate the plates aerobically at $37^{\circ} \mathrm{C}$ for $24 \mathrm{~h}$ and then check for the bacterial growth.

4. As expected, no bacterial colonies appear on the plates containing gut homogenates from the dechorionated eggs provided with food supplemented with antibiotics (Dechorionated eggs + food with antibiotics, Figure 4). However, bacterial colonies grow up on the plates containing gut homogenates from other three groups (Figure 4). Consequently, the evidence suggests that RPW GF larvae were generated successfully. 


\section{bĭo-protocol

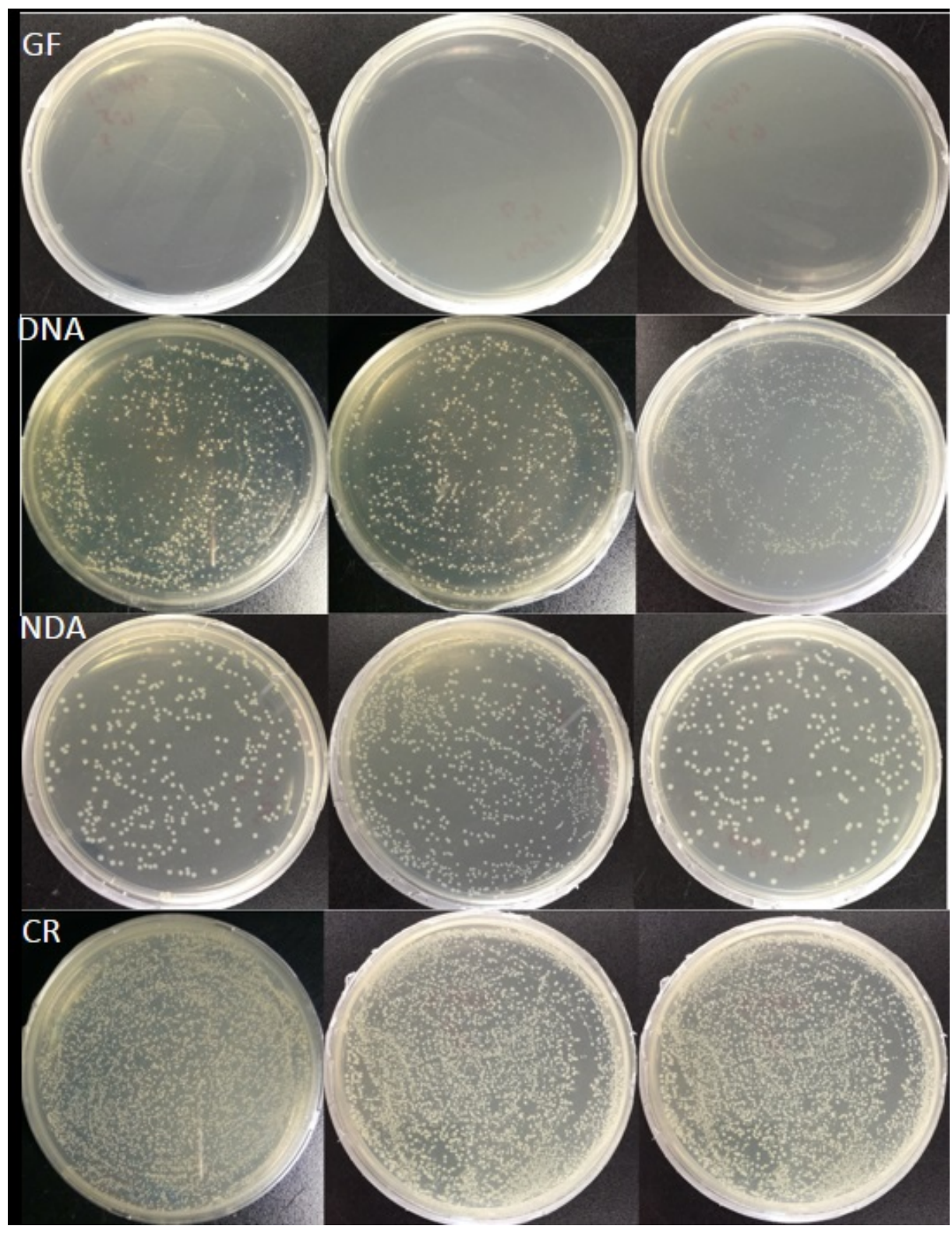

Figure 4. Culture-dependent verification of bacterial growth in the guts of RPW larvae from different treatment cohorts. No bacterial colony is observed in the larvae guts from germ-free (GF) group: dechorionated eggs reared on antibiotic treated food (Dechorionated + food with antibiotic). However, bacterial colonies were found in other three treatment cohorts: DNA (dechorionated eggs + food without antibiotics), NDA (non-dechorionated eggs + food with antibiotics) and CR conventionally reared (non-dechorionated eggs + food without antibiotics).

\section{Confirmation of germfree RPW individuals with culture-independent assays}

1. The lysed guts in Step D4 (gut dissection and homogenization) were employed to extract the total gut bacteria DNA with DNeasy blood and tissue Kit (Qiagen) following the manufacturer guidelines. 
2. Repeat the final elution twice in $80 \mu \mathrm{l}$ buffer $A E$ for improving DNA yield.

3. Quantify the purity and concentration of the extracted DNA by running on $1 \%$ gel stained with ethidium bromide and using Nanodrop 1000 (Thermo Scientific, USA).

4. Prepare the $25 \mu \mathrm{IPCR}$ reaction system:

50 ng template DNA

$1 \mu \mathrm{l}$ of each forward (27F: 5'-AGAGTTTGATCATGGCTCAG-3') and reverse primer (1492R:

5'-TACGGYTACCTTGTTACGACTT-3')

$12.5 \mu$ of $2 x$ Taq PCR Mastermix (Tiangen Biotechnology Beijing, China)

Up to $25 \mu$ with PCR grade $d_{d H_{2}} \mathrm{O}$

5. Set up a negative control for PCR by adding $1 \mu \mathrm{PCR}$ grade $\mathrm{ddH}_{2} \mathrm{O}$ as a template while other reagents remain the same.

6. Run PCR reactions with the thermal conditions as in Table 1.

Table 1. The thermal conditions of Bacterial 16R rRNA-based PCR assays

\begin{tabular}{llll}
\hline Steps & Temperature & Time & Cycles \\
\hline Initial denaturation & $94^{\circ} \mathrm{C}$ & $3 \mathrm{~min}$ & 1 \\
Denaturation & $94^{\circ} \mathrm{C}$ & $30 \mathrm{~s}$ & 30 \\
Annealing & $55^{\circ} \mathrm{C}$ & $30 \mathrm{~s}$ & \\
Extension & $72{ }^{\circ} \mathrm{C}$ & $60 \mathrm{~s}$ & \\
Final extension & $72{ }^{\circ} \mathrm{C}$ & $7 \mathrm{~min}$ & 1 \\
Hold & $4{ }^{\circ} \mathrm{C}$ & Indefinite & \\
\hline
\end{tabular}

7. Detect the PCR products with electrophoresis on $1 \%$ agarose gel. Prepare a $1 \%$ agarose gel by dissolving $1.0 \mathrm{~g}$ agarose in $100 \mathrm{ml} 0.5 \mathrm{x}$ TAE buffer and microwave the solution until it has completely dissolved.

8. Carefully pour the gel solution in an agarose gel cast tray to avoid bubbles formation and let it polymerize for at least $30 \mathrm{~min}$.

9. Place the gel in the electrophoresis unit filled with $0.5 x$ TAE buffer.

10. Mix $4 \mu \mathrm{l}$ of PCR products with $1 \mu \mathrm{l}$ loading buffer and add to the wells of the gel.

11. Load $5 \mu \mathrm{l} 2,000$ bp DNA marker and run the gel for $30 \mathrm{~min}$ at $90 \mathrm{~V}$.

12. Visualize the gel under the UV light to detect the target band with the expected size of 1,500 bp.

13. No target PCR band is observed in RPW GF larvae, it presents in other three groups (Figure 5). This result is line with that of culture-dependent method. 


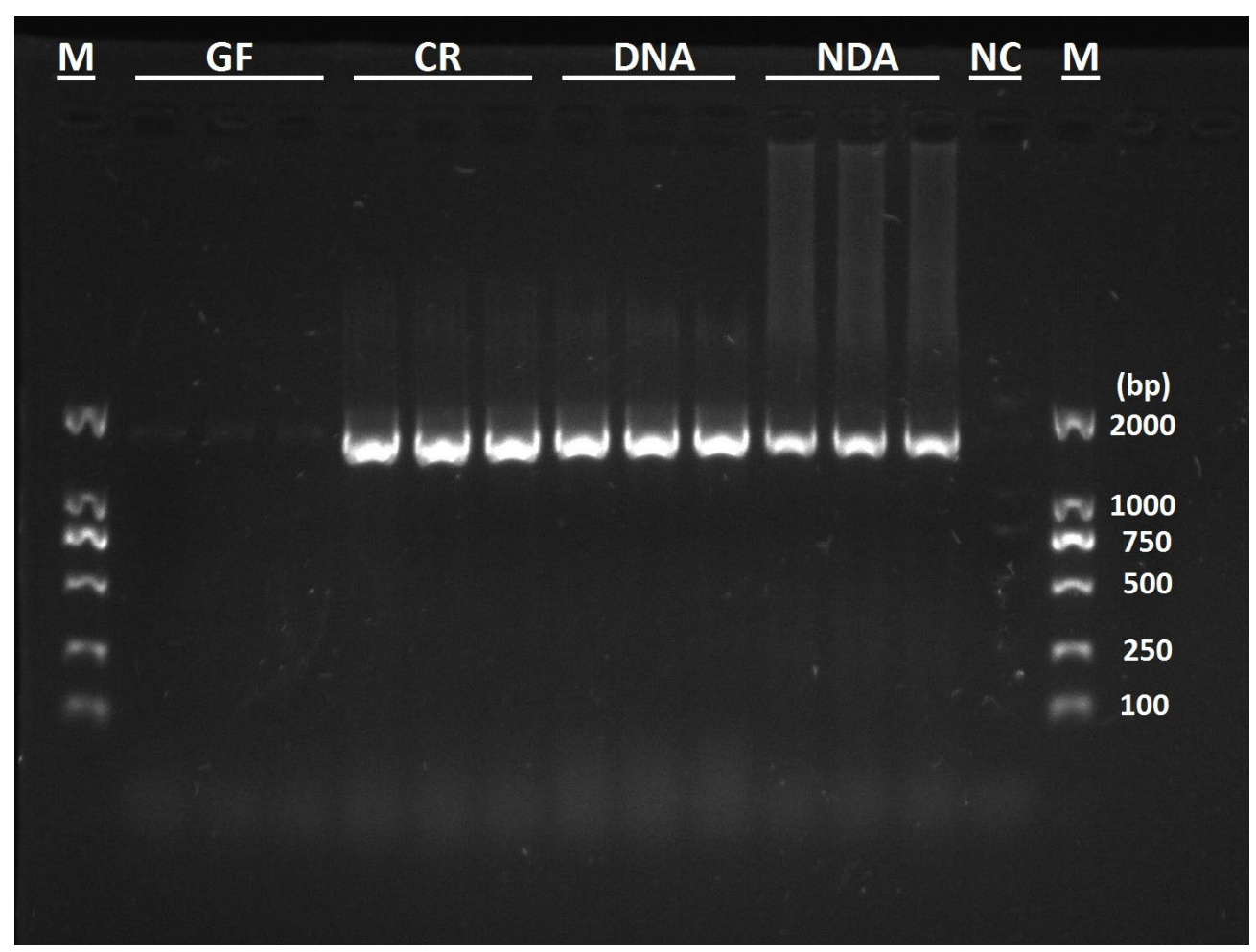

Figure 5. Verification of gut bacteria-derived PCR products with bacterial $16 \mathrm{~S}$ rRNA-based PCR assays. GF (Dechorionated eggs + food with antibiotics), DNA (dechorionated eggs + food without antibiotics) NDA (non-dechorionated eggs + food with antibiotics) and CR conventionally reared (non-dechorionated eggs + food without antibiotics).

E. Conclusion

Here, we developed a protocol to generate RPW germ-free larvae for further investigation on the interplays between RPW larvae and their associated gut bacteria. This method requires strict sterile conditions, in other words, each step in our protocol should be completed inside the laminar hood. Taken together, following our reported protocol here, RPW GF larvae can be generated from dechorionated eggs which are reared on sterilized artificial food under axenic conditions.

\section{Data analysis}

Run a One-way Analysis of Variance (ANOVA) to determine the significance in bacterial CFUs across the different treatment groups. Significant differences were determined in the number of bacterial colonies across different cohorts. The guts of RPW individuals from DNA and NDA group were colonized by significantly less bacteria colonies as compared to CR insects (Figure 6). 


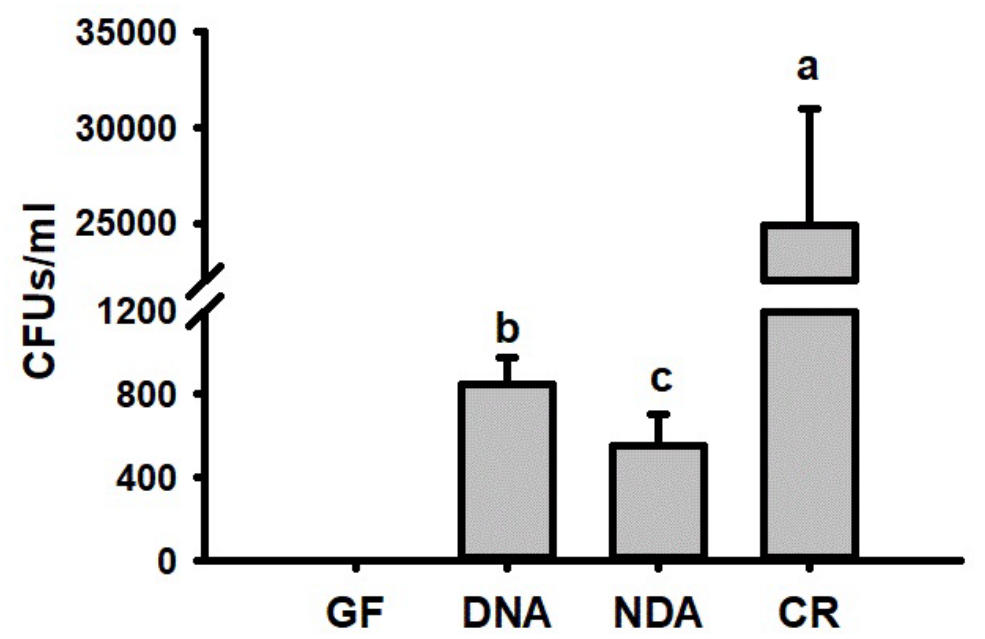

Figure 6. Quantification of bacterial colony forming units (CFUs) in the guts of RPW larvae from different treatment groups. The number of CFUs of each plate was counted $24 \mathrm{~h}$ after incubation at $37^{\circ} \mathrm{C}$. A One-way ANOVA (Tukey's HSD post hoc multiple comparisons) was run to detect the statistical differences of bacterial CFU across the treatments. The letters indicate significance at $P<0.05$. GF (Dechorionated eggs + food with antibiotics), DNA (dechorionated eggs + food without antibiotics), NDA (non-dechorionated eggs + food with antibiotics) and CR conventionally reared (non-dechorionated eggs + food without antibiotics).

\section{Recipes}

1. The artificial food for RPW larvae (Table 2)

Table 2. Composition of artificial diet used for RPW rearing

\begin{tabular}{ll}
\hline Ingredients & Quantity \\
\hline Date palm tissue & $8.0 \mathrm{~g}$ \\
Sucrose & $8.0 \mathrm{~g}$ \\
Agar & $6.0 \mathrm{~g}$ \\
Casein & $8.0 \mathrm{~g}$ \\
Corn flour & $10.0 \mathrm{~g}$ \\
Yeast extract & $12.0 \mathrm{~g}$ \\
Avicel & $5.0 \mathrm{~g}$ \\
Ascorbic acid as vitamin C & $1.0 \mathrm{~g}$ \\
Potassium sorbate & $0.4 \mathrm{~g}$ \\
Sodium p-hydroxybenzoate & $0.2 \mathrm{~g}$ \\
Cholestrol & $0.3 \mathrm{~g}$ \\
Choline chloride & $0.25 \mathrm{~g}$ \\
Inositol & $0.02 \mathrm{~g}$ \\
Distilled water & $220 \mathrm{ml}$ \\
\hline
\end{tabular}


2. Antibiotic stock solution (Table 3)

Table 3. Preparation of antibiotics stock and working concentrations

\begin{tabular}{lcccc}
\hline Antibiotic & $\begin{array}{c}\text { Stock solution } \\
\text { concentration } \\
(\mathrm{mg} / \mathrm{ml})\end{array}$ & Solvent & $\begin{array}{c}\text { Storage } \\
\text { temperature }\end{array}$ & $\begin{array}{c}\text { Final } \\
\text { concentration } \\
(\mathrm{mg} / \mathrm{Kg})\end{array}$ \\
\hline Erythromycin & 20 & $\mathrm{EtOH}$ & $-20^{\circ} \mathrm{C}$ & 150 \\
Gentamycin & 10 & $\mathrm{H}_{2} \mathrm{O}$ & $-20^{\circ} \mathrm{C}$ & 150 \\
Kanamycin & 50 & $\mathrm{H}_{2} \mathrm{O}$ & $4{ }^{\circ} \mathrm{C}$ & 150 \\
Tetracycline & 15 & $\mathrm{EtOH}$ & $-20^{\circ} \mathrm{C}$ & 150 \\
\hline
\end{tabular}

3. 10x PBS stock solution

a. Prepare PBS stock solution (10x) by dissolving $80 \mathrm{~g} \mathrm{NaCl}, 2 \mathrm{~g} \mathrm{KCl}, 14.4 \mathrm{~g} \mathrm{Na}_{2} \mathrm{HPO}_{4}$, and $2.4 \mathrm{~g} \mathrm{KH}_{2} \mathrm{PO}_{4}$ into $800 \mathrm{ml}$ distilled water in a conical flask

b. Mix it well on a magnetic stirrer and adjust $\mathrm{pH}$ to 7.4 with $\mathrm{HCl}$ in a final volume of $1 \mathrm{~L}$

c. Autoclave the solution for $20 \mathrm{~min}$ at $121^{\circ} \mathrm{C}$ and store in aliquots at $4{ }^{\circ} \mathrm{C}$

4. LB agar medium

a. Take $5 \mathrm{~g}$ tryptone, $5 \mathrm{~g} \mathrm{NaCl}, 2.5 \mathrm{~g}$ yeast extract, $7.5 \mathrm{~g}$ agar and add it to a $400 \mathrm{ml}$ distilled water. Mix it well in a $1 \mathrm{~L}$ conical flask.

b. Adjust the $\mathrm{pH}$ to 7.0 with $\mathrm{NaOH}$ in a final volume of $500 \mathrm{ml}$

c. Autoclave the media for $20 \mathrm{~min}$ at $121^{\circ} \mathrm{C}$

d. Let the agar cool down to $55^{\circ} \mathrm{C}$ and then pour $(20 \mathrm{ml})$ it into sterilized Petri dishes

e. Let it polymerize for about $40 \mathrm{~min}$ and then seal it with parafilm

f. Store the LB agar plates in the fridge at $4{ }^{\circ} \mathrm{C}$

5. 10x TAE stock solution

a. Prepare TAE stock solution (10x) by dissolving $48.4 \mathrm{~g}$ Tris, $11.4 \mathrm{ml}$ of glacial acetic acid and $3.7 \mathrm{~g}$ disodium EDTA in $800 \mathrm{ml}$ distilled water

b. Stir the solution until dissolved completely and make the final volume $1 \mathrm{~L}$ with distilled water. There is no need to sterilize the solution and store it at room temperature

\section{Acknowledgments}

We are very indebted to the financial support from National Natural Science Foundation of China (31470656), the National Key Research and Development Project of China (2017YFC1200605) and Natural Science Foundation of Fujian Province (2018J01705). This protocol was modified from our previous work (doi:10.3389/fmicb.2019.01212) which has been published in Frontiers in Microbiology. 
Please cite this article as: Muhammad et. al., (2019). Preparation of Red Palm Weevil Rhynchophorus Ferrugineus (Olivier) (Coleoptera: Dryophthoridae) Germ-free Larvae for Host-gut Microbes Interaction Studies,Bio-protocol 9 (24): e3456. DOI: 10.21769/BioProtoc.3456.

\section{Competing interests}

The authors declare that they do not have any competing interest.

\section{Ethics}

Rhynchophorus ferrugineus individuals are treated according to the standard ethical protocol.

\section{$\underline{\text { References }}$}

1. Al-Dosary, N. M., Al-Dobai, S. and Faleiro, J. R. (2016). Review on the management of red palm weevil Rhynchophorus ferrugineus olivier in date palm Phoenix dactylifera L. Emir J Food Agr 28(1): 34-44.

2. Butera, G., Ferraro, C., Colazza, S., Alonzo, G. and Quatrini, P. (2012). The culturable bacterial community of frass produced by larvae of Rhynchophorus ferrugineus Olivier (Coleoptera: Curculionidae) in the Canary island date palm. Lett Appl Microbiol 54(6): 530-536.

3. Crotti, E., Balloi, A., Hamdi, C., Sansonno, L., Marzorati, M., Gonella, E., Favia, G., Cherif, A., Bandi, C., Alma, A. and Daffonchio, D. (2012). Microbial symbionts: a resource for the management of insect-related problems. Microb Biotechnol 5(3): 307-317.

4. Dawadi, B., Wang, X., Xiao, R., Muhammad, A., Hou, Y. and Shi, Z. (2018). PGRP-LB homolog acts as a negative modulator of immunity in maintaining the gut-microbe symbiosis of red palm weevil, Rhynchophorus ferrugineus Olivier. Dev Comp Immunol 86: 65-77.

5. Douglas, A. E. (2009). The microbial dimension in insect nutritional ecology. Funct Ecol 23(1): 38-47.

6. Douglas, A. E. (2010). The symbiotic habit. Princeton University Press.

7. Douglas, A. E. (2015). Multiorganismal insects: diversity and function of resident microorganisms. Annu Rev Entomol 60: 17-34.

8. El-Mergawy, R. A. A. M. and Al-Ajlan, A. M. (2011). Red palm weevil, Rhynchophorus ferrugineus (olivier): Economic importance, biology, biogeography and integrated pest management. J Agr Sci Tech A (1): 1-23.

9. Engel, P. and Moran, N. A. (2013). The gut microbiota of insects-diversity in structure and function. FEMS Microbiol Rev 37(5): 699-735.

10. Faleiro, J. R. (2006). A review of the issues and management of the red palm weevil Rhynchophorus ferrugineus (Coleoptera: Rhynchophoridae) in coconut and date palm during the last one hundred years. Int J Trop Insect Sci 26(3): 135-154.

11. Grover, M. and Kashyap, P. C. (2014). Germ-free mice as a model to study effect of gut microbiota on host physiology. Neurogastroenterol Motil 26(6): 745-748.

12. Habineza, P., Muhammad, A., Ji, T., Xiao, R., Yin, X., Hou, Y. and Shi, Z. (2019). The promoting effect of gut microbiota on growth and development of Red Palm Weevil, Rhynchophorus 
Please cite this article as: Muhammad et. al., (2019). Preparation of Red Palm Weevil Rhynchophorus Ferrugineus (Olivier) (Coleoptera: Dryophthoridae) Germ-free Larvae for Host-gut Microbes Interaction Studies,Bio-protocol 9 (24): e3456. DOI: 10.21769/BioProtoc.3456.

ferrugineus (Olivier) (Coleoptera: Dryophthoridae) by modulating its nutritional metabolism. Front microbiol 10: 1212.

13. Jia, S., Zhang, X., Zhang, G., Yin, A., Zhang, S., Li, F., Wang, L., Zhao, D., Yun, Q., Tala, Wang, J., Sun, G., Baabdullah, M., Yu, X., Hu, S., Al-Mssallem, I. S. and Yu, J. (2013). Seasonally variable intestinal metagenomes of the red palm weevil (Rhynchophorus ferrugineus). Environ Microbiol 15(11): 3020-3029.

14. Ju, R. T., Wang, F., Wan, F. H. and Li, B. (2011). Effect of host plants on development and reproduction of Rhynchophorus ferrugineus (Olivier) (Coleoptera: Curculionidae). J Pest Sci 84(1): 33-39.

15. Kaakeh, W. (2005). Longevity, fecundity, and fertility of the red palm weevil, Rynchophorus ferrugineus Olivier (Coleoptera: Curculionidae) on natural and artificial diets. Emir J Agric Sci 17(1): 23-33.

16. Kietz, C., Pollari, V. and Meinander, A. (2018). Generating germ-free Drosophila to study gut-microbe interactions: protocol to rear Drosophila under axenic conditions. Curr Protoc Toxicol 77(1).

17. Koyle, M. L., Veloz, M., Judd, A. M., Wong, A. C., Newell, P. D., Douglas, A. E. and Chaston, J. M. (2016). Rearing the fruit fly Drosophila melanogaster under axenic and gnotobiotic conditions. J Vis Exp (113): e54219.

18. Li, Y., Zhu, Z., Ju., R. and Wang, L. (2009). The red palm weevil, Rhynchophorus ferrugineus (Coleoptera: Curculionidae), newly reported from Zhejiang, China and update of geographical distribution. Florida Entomologist 92(2): 386-387.

19. Mazza, G., Francardi, V., Simoni, S., Benvenuti, C., Cervo, R., Faleiro, J. R., Llácer, E., Longo, S., Nannelli, R., Tarasco, E. and Roversi, P. F. (2014). An overview on the natural enemies of Rhynchophorus palm weevils, with focus on R. ferrugineus. Biol Control 77: 83-92.

20. Montagna, M., Chouaia, B., Mazza, G., Prosdocimi, E. M., Crotti, E., Mereghetti, V., Vacchini, V., Giorgi, A., De Biase, A., Longo, S., Cervo, R., Lozzia, G. C., Alma, A., Bandi, C. and Daffonchio, D. (2015). Effects of the diet on the microbiota of the red palm weevil (Coleoptera: Dryophthoridae). PLoS ONE 10(1): e0117439.

21. Muhammad, A., Fang, Y., Hou, Y. and Shi, Z. (2017). The Gut Entomotype of Red Palm Weevil Rhynchophorus ferrugineus Olivier (Coleoptera: Dryophthoridae) and their effect on host nutrition metabolism. Front Microbiol 8: 2291.

22. Murphy, S. T. and Briscoe, B. R. (1999). The red palm weevil as an alien invasive: biology and the prospects for biological control as a component of IPM. Biocontrol News Inform 20(1): $35 \mathrm{~N}-46 \mathrm{~N}$.

23. OEPP/EPPO (2008). Data sheets on quarantine pests: Rhynchophorus ferrugineus. Bulletin OEPP 38: 55-59.

24. Peng, L., Miao, Y. and Hou, Y. (2016). Demographic comparison and population projection of Rhynchophorus ferrugineus (Coleoptera: Curculionidae) reared on sugarcane at different temperatures. Sci rep-UK 6: e31659. 
25. Pu, Y. and Hou, Y. (2016). Isolation and identification of bacterial strains with insecticidal activities from Rhynchophorus ferrugineus Oliver (Coleoptera: Curculionidae). J Appl Entomol 140: 617-626.

26. Shi, Z. H., Lin, Y. T. and Hou, Y. M. (2014). Mother-derived trans-generational immune priming in the red palm weevil, Rhynchophorus ferrugineus Olivier (Coleoptera, Dryophthoridae). Bull Entomol Res 104(6): 742-750.

27. Tagliavia, M., Messina, E., Manachini, B., Cappello, S. and Quatrini, P. (2014). The gut microbiota of larvae of Rhynchophorus ferrugineus Olivier (Coleoptera: Curculionidae). BMC microbiol 14(1): 136.

28. Xiao, R., Wang, X., Xie, E., Ji, T., Li, X., Muhammad, A., Yin, X., Hou, Y. and Shi, Z. (2019). An IMD-like pathway mediates the intestinal immunity to modulate the homeostasis of gut microbiota in Rhynchophorus ferrugineus Olivier (Coleoptera: Dryophthoridae). Dev Comp Immunol 97: 20. 